\section{DIGITAL COMMONS \\ @ UNIVERSITY OF SOUTH FLORIDA}

\section{ABO: Interactive Journal for Women in the Arts, 1640-1830}

Volume 3

Issue 2 Volume 3.2 (Fall 2013)

Article 3

2013

\title{
Matters of Fact in Jane Austen: History, Location, and Celebrity, by Janine Barchas
}

Laura E. Thomason

Macon State College, laura.thomason@maconstate.edu

Follow this and additional works at: https://digitalcommons.usf.edu/abo

Part of the Dramatic Literature, Criticism and Theory Commons, Educational Methods Commons, Feminist, Gender, and Sexuality Studies Commons, and the Literature in English, British Isles Commons

\section{Recommended Citation}

Thomason, Laura E. (2013) "Matters of Fact in Jane Austen: History, Location, and Celebrity, by Janine Barchas," ABO: Interactive Journal for Women in the Arts, 1640-1830: Vol.3: Iss.2, Article 3.

http://dx.doi.org/10.5038/2157-7129.3.2.3

Available at: https://digitalcommons.usf.edu/abo/vol3/iss2/3

This Reviews is brought to you for free and open access by Digital Commons @ University of South Florida. It has been accepted for inclusion in ABO: Interactive Journal for Women in the Arts, 1640-1830 by an authorized administrator of Digital Commons @ University of South Florida. For more information, please contact digitalcommons@usf.edu. 


\section{Matters of Fact in Jane Austen: History, Location, and Celebrity, by Janine Barchas}

\section{Keywords}

Jane Austen, Janine Barchas, history, celebrity, culture, eighteenth century

\section{Creative Commons License}

\section{(c) $($ ) $\odot$}

This work is licensed under a Creative Commons Attribution-No Derivative Works 3.0 License. 
Janine Barchas. Matters of Fact in Jane Austen: History, Location, and Celebrity. Baltimore: The Johns Hopkins UP, 2012. Xiii + 307 pages. Index. ISBN: 978-1-4214-0640-4.

Reviewed by Laura E. Thomason

Middle Georgia State College

In Matters of Fact in Jane Austen: History, Location, and Celebrity, Janine Barchas counters the ahistorical readings that have long been characteristic of Austen criticism and advances in their place a series of highly detailed historical interpretations. Barchas attributes the ahistorical or even anti-historical approaches to three factors: traditional sensibilities that have kept Austen's image as a cozy domestic novelist stubbornly intact, Romantic ideals that privileged originality and imagination, and Austen's position as a transitional figure spanning the eighteenth and nineteenth centuries. Now that Austen's place in the literary canon is enduringly established, her works have begun to attract historicist readings and related scholarship (including Barchas's own recently launched online project "What Jane Saw"). Barchas builds her comprehensive study on these foundations, "corralling prior scholarly insights" and drawing new connections in order to show that a consistent historicism is present in Austen (3). Examining the local and national history with which Austen grew up and the published accounts then available to her, Barchas establishes a persuasive and particular account of the ways in which Austen used that information. "Dear Aunt Jane" becomes, in Barchas's reading, an expert on local places, local history, and local celebrity culture. Moving away from domesticity and beyond broad social history, Matters of Fact in Jane Austen proceeds as a series of detailed case studies that, taken together, make a strong argument for Austen as a popular culture aficionado and for scholars' attachment to her vaunted "timelessness" as a disservice to her powers of observation and allusion.

Barchas begins by examining Austen's "promiscuous" borrowing of names from across the political spectrum. She builds on the work of Donald Greene and others who have documented Austen's use of names from the prominent Wentworth family including Fitzwilliam, Woodhouse, Darcy, and Watson. Focusing on both the Whig and the Tory branches of the Wentworths, Barchas demonstrates Austen's engagement with "cultural history" as she traces the resemblances between the Wentworths' rivalry and events in Persuasion and Lady Susan (29). Although the Wentworths lived in Yorkshire, their legal infighting and competitive estateimproving were, as Barchas establishes, nationally known. She documents the extent of Austen's probable knowledge of the Wentworth family's history and uses that information to suggest that Persuasion, Lady Susan, and even Emma deliberately echo or invert various Wentworth family dramas. Furthermore, she points to the notorious Vernon branch of the Wentworths to suggest a possible date for Lady Susan based on press accounts of Vernon family scandals during Austen's lifetime. Throughout her study, Barchas points to Austen's participation in and updating of a "cratylic" tradition that would have been a familiar practice to readers and writers conversant with Squire Allworthy, Betsy Thoughtless, and similarly named characters (135). The suggestion, then, is that while Austen was far from writing romans à clef, her frame of reference extended far beyond her immediate family and friends and invited readers to notice the similarities among her characters and their historical counterparts. Read thusly, her novels become oblique commentaries on the popular culture of her time. 
Matters of Fact in Jane Austen also reconstructs locations likely to have been familiar to Austen and explains the connections between those locations, the prominent people who lived there, and the locations and characters in Austen's works. Barchas convincingly suggests, for example, that Northanger Abbey's Catherine Morland is mistaken for an heiress because her guardians in Bath are a Mr. and Mrs. Allen. The name "Allen" suggests to the other characters-and, by extension, to Austen's original readership_-Ralph Allen, Bath's wealthiest entrepreneur and "a nationally recognized figure...often referred to simply as "the Man of Bath'" (57). The fact that the Allen fortune was in transition at the time of Northanger Abbey's composition lends further credence to this topical and historically contingent reading. Barchas further demonstrates Northanger Abbey's reliance on a detailed knowledge of Bath's geography and the sights to be seen there. Using popular tourist maps from the turn of the nineteenth century to correlate the characters' movements with actual locations in Bath, Barchas suggests that a "Bath-savvy" audience would have made those correlations themselves and used them to judge the characters' actions (63). Readers who knew that Ralph Allen's "Sham Castle," a famous faux-Gothic edifice, was visible from Bath's main streets, would have seen John Thorpe's offer to drive Catherine Morland fifty miles to see Blaise Castle as a clear confirmation of his "misleading influence" (81). Catherine moves away from the Sham Castle through streets and past buildings whose names Austen specifies, emphasizing Catherine's naïveté by implying a contrast with a knowledgeable reader's understanding. This and similar interpretations throughout Matters of Fact in Jane Austen make a case for Austen as a shrewd cultural observer.

Although this study is meticulously researched, Barchas sometimes relies on associations as well as facts and thus occasionally takes a speculative tone that can seem frustrating. This tentativeness, however necessary, makes the book a bit less satisfying. The final chapter examines Austen's invocations of the Navy List and Debrett's Baronetage in Persuasion. It is less definitive, albeit responsibly argued, when Barchas suggests that Austen may have been responding to financial pressures in her own family when she created a balanced vision that heralded the virtues of self-made military men and those of traditional landed gentry. But the same chapter is more persuasive when it suggests that Persuasion purposefully emphasizes the similarities between naval officers and baronets while downplaying their differences. Both groups, Barchas illustrates, had to rely on a combination of hard work and good luck to achieve advancement: when Austen "shows mixed sympathies" in Persuasion, she also invokes the changing nature of social mobility in her time (254).

Overall, Barchas's argument is carefully defined and intelligently limited, making the most of what is knowable and acknowledging that some specifics are lost to history. Matters of Fact in Jane Austen offers a highly detailed, thoroughly researched study of people and places that, while wellknown in Austen's time, have been forgotten, overlooked, or ignored as likely influences on her work. Examining names, locations, architectural details, and landscape features among other factors, Barchas constructs an image of Jane Austen as a highly topical author who participated in celebrity culture, studied local history, and closely followed contemporary events. The result is a convincing re-evaluation of Austen that places her works in relationship to those of her contemporary Sir Walter Scott and creates an image of Austen as an engaged and vigorous observer and commentator on her culture. 